\title{
ANALYSIS OF BIOCHEMICAL PROPERTIES RELATED TO HARD BUNCH PHENOMENA IN OIL PALM (Elaeis guineensis Jacq.)
}

\author{
ROBERDI, ROBERDI*; SOBIR, SOBIR ${ }^{\star *}$; YAHYA, SUDIRMAN**; TORUAN-MATHIUS, \\ NURITA* and LIWANG, TONY*
}

\begin{abstract}
Hard bunch is an abnormal phenomenon occurred on fruits of oil palm. This abnormality exists in several oil palm plantations in Indonesia and typically, hard bunch occurs in areas which are frequently dry. Up to this point, the hard bunch biochemical properties are not well understood and therefore, many researchers are trying to elucidate this abnormality. The objective of this study was to characterise the biochemical properties related to the abnormal oil palm fruits. The fruits samples which were collected from the oil palm plantation in Lampung were subjected to the physical and biochemical properties analysis of the bunches. Analyses performed on the bunch were carotenoids, tocopherol, phenolic acids, lignin and oil extraction ratio. The experimental results indicated that fresh fruit bunch, spikelet weight, total carotene, 4-hydroxybenzoic acid, chlorogenic acid, ferulic acid and lignin of fruit abscission zone observed from normal and hard bunches were significanly different. On the other hand, the other parameters were not significantly different. However, lignin accumulation in the abscission zone which affects the loosenes of fruits from the bunch, indicated high level in the hard bunch abnormality (76.41\%) compared to that of normal oil palm $(70.61 \%)$.
\end{abstract}

Keywords: abnormality fruits, drought stress, lignin content.

Date received: 7 April 2015; Sent for revision: 1 July 2015; Received in final form: 7 March 2016; Accepted: 13 April 2016.

\section{INTRODUCTION}

Indonesia has the largest oil palm plantation in the world with the total area of 9.1 million hectares in 2013 (www.ditjenbun.pertanian.go.id). Recently, the expansion of oil palm plantation has moved into

\footnotetext{
* PT SMART - Biotechnology,

Jalan Raya Cijayanti Kp Pasirmaung,

RT 004/006 Babakan Madang,

Bogor, West Java 16145,

Indonesia.

E-mail: roberdi_siberakuno@yahoo.co.uk

** Faculty of Agriculture,

Bogor Agricultural University,

Bogor, West Java,

Indonesia.
}

marginal lands which are typically less suitable for oil palm cultivation. For optimum growth, oil palm requires evenly distributed rainfall of $2000 \mathrm{~mm} \mathrm{yr}^{-1}$ (Corley and Tinker, 2003). The rapid expansion of oil palm plantations in Indonesia has reached some areas where the dry season is much longer than other areas. Drought period in these dry areas usually occurs for three to four months with monthly rainfall ranging from $0-100 \mathrm{~mm}$. The occurrence of abnormalities to oil palm fruits becomes one of the major problems for oil palm cultivation in such areas.

The abnormalities in the oil palm plantation in areas which are frequently dry include the nonshed ripe fruits in the field and fruits which remain attached to the bunch after the fruit separation stage 
at the mill. This phenomenon is called 'hard bunch', which only occurs in regions which have lengthy dry period in a year. Hard bunch is caused by water shortage because of inadequate distribution of rainfall and climatic factors which accelerate the loss of water from the soil and air. Hard bunch phenomenon has a significant correlation with rainfall for six to nine months before the bunch harvested (Roberdi, 2014).

The presence of loose fruits (shed fruits) is one of the harvesting criteria being used to define fruit ripening in oil palms. If loose fruits are not observed on the ground at the palm base, fruits ripening cannot be detected from hard bunches, therefore, ripening fruit bunches will not be harvested. As a consequence the hard bunch phenomena can result in decreasing productivity in the oil palm plantation. The hard bunch incidence in the oil palm plantations is quite high ranging from $13.35 \%-21.36 \%$ between 2007 - 2012 (RC Lampung, pers. comm.).

Neo et al. (2008) reported that palm oil contains many antioxidants such as carotenoid, tocopherol, and phenolic compounds which may contribute to human health. These compounds are known to be involved in plant defense mechanisms against drought stress. The fruits from hard bunches are different from normal fruits in terms of the colour and mesocarp structure, and these may be due to the differences of biochemical compound profile of the fruits. Therefore, analysis of the essential biochemical compounds is required for the two types of fruits.

Several researchers have analysed biochemical components in extract of normal oil palm fruits. There are eight phenolic acids types in palm oil extract discovered by Neo et al. (2008), high concentration of tocols in palm oil was detected by $\mathrm{Ng}$ et al. (2004) and high concentration of $\alpha$ and $\beta$ carotene was reported by Ping and Gwendoline (2006) on ripe oil palm fruit extract. On the other hand, similar biochemical component analysis on fruits from hard bunches has not been performed and to our knowledge no such report have been published.

Besides previous report on biochemical properties of normal bunch, biochemical properties in the fruit mesocarp from both hard bunch and normal bunch are equally important in order to elucidate fruits abnormality in oil palm cultivated in dry areas. The mesocarp of fruits from a hard bunch was observed to be enriched with high fibre composition which is supposedly a long chain polysaccharide such as lignin and pectin. These compounds are the cell wall components and predominantly accumulated in the secondary cell wall. The lignin biosynthesis can be induced in response to different biotic and abiotic stresses (Cano-Delgado et al., 2003). Drought stress also can activate the genes involved in lignin biosynthesis
(Bok-Rye et al., 2007; Yoshimura et al., 2008). Other biochemical characters were analysed to observe further differences between hard and normal bunches. The objective of this study was to characterise the biochemical components related to hard bunch in oil palm fruits.

\section{MATERIALS AND METHODS}

\section{Plant Materials and Sampling Procedure}

The hard and normal bunches were collected from adjacent 20 years old tenera $(\mathrm{D} \times \mathrm{P})$ palms in Lampung Plantation, 20 bunches each and brought to the laboratory for analysis. The analysis was carried out on physical and chemical properties of the oil palm fruits, such as carotenoid and tocopherol content, phenolic compound, and lignin content.

\section{Bunch Analysis}

The method of bunch analysis was performed according to the plantation standard operating procedure. The ripe bunches were harvested, labelled and brought to the laboratory for further analysis. The fresh fruit bunch (FFB) was weighed, the spikelets were chopped and counted. Oil contents to bunch was derived from $3.5 \mathrm{~kg}$ of fruit samples which were taken from 25 spikelets (8:9:8 ratio) at three different zones of the bunch (up, middle and down) respectively. From these zones, 10 spikelets (3:4:3 ratio) from each zone were selected randomly. Three fruits from each spikelet (30 fruits) which represented each zone of spikelet were weighed and the mesocarp was separated from the nuts. Wet mesocarp and nut were weighed and dried for $12 \mathrm{hr}$ at $80^{\circ} \mathrm{C}$ to measure the dry weight of mesocarp and nuts. In addition, others parameters, such as total normal fruits and infertile fruits were also observed. The oil was extracted with hexane methods (MPOB, 2005).

\section{Carotenoid and Tocopherol Analysis}

The carotenes and tocols were extracted following the procedure described by Ping and Gwendoline (2006) with minor modification. Total carotenoid content was determined by the spectrophotometric method. One hundred milligrams of oil was weighed, dissolved in $3 \mathrm{ml}$ hexane and vortexed. The solution was measured at wavelength $446 \mathrm{~nm}$ (MPOB, 2005). The total carotenoids content was expressed based on $\beta$-carotene equivalent ( $\beta$-carotene; $\mathrm{mg} / 100 \mathrm{~g}$ fresh mass).

The carotenoid profiles were obtained based on Acquity column UPLC BEH C18 $1.7 \mu \mathrm{m}(2.1 \times 50$ $\mathrm{mm}$ ) (Waters) using PDA detector. As mobile phase, a 
mixture of acetonitrile: methanol $(20: 80 \mathrm{v} / \mathrm{v})$ with 0.4 $\mathrm{ml} \mathrm{min} \mathrm{m}^{-1}$ eluent was used. The column was properly maintained at ambient laboratory temperature and sample was measured at wavelength of $450 \mathrm{~nm}$ (Ping and Gwendoline, 2006). The reliability of this method was justified by using standard curve of 100 - 500 ppm of $\beta$-carotene.

Tocopherol concentration was determined with similar procedure and detector. This compound was measured at wavelength $292 \mathrm{~nm}$ and as standard curve was 0 - 500 ppm of $\alpha$-tocopherol.

\section{Phenolic Compound}

Extraction and quantification of phenolic compounds were performed based on methods described by Fuchs et al. (2010) with minor modification. The ripe fruit mesocarp was separated from the nuts and ground to fine powder. One gram of sample was dissolved with $50 \mathrm{ml}$ of $2 \mathrm{M} \mathrm{HCl}$ : methanol (1:1). The sample was ultrasonicated for $60 \mathrm{~min}$ at $60^{\circ} \mathrm{C}$, and filtered. The mixture was evaporated, and dry filtrate was dissolved with 50 $\mathrm{ml}$ aquades. The sample was further extracted for three times with $20 \mathrm{ml}$ of diethyl ether. Organic layer was separated and evaporated. The dry residue was dissolved in $2 \mathrm{ml}$ of methanol.

\section{Analysis of Total Phenolics with Folin-ciocalteu Assay}

Total phenolic compounds were analysed based on the method described by Fuchs et al. (2010). Mixture consisting of $40 \mu \mathrm{l}$ of extract, $2 \mathrm{ml}$ of $\mathrm{H}_{2} \mathrm{O}, 100 \mu \mathrm{l}$ of Folin-Ciocalteu Reagen (2N), was incubated for $3 \mathrm{~min}$. Two hundreds microlitres of $\mathrm{Na}_{2} \mathrm{CO}_{3}$ (35 g in $100 \mathrm{ml} \mathrm{H} \mathrm{H}_{2} \mathrm{O}$ ), and $2660 \mu \mathrm{l}$ of $\mathrm{H}_{2} \mathrm{O}$ were added to the mixture and the absorbance spectra was measured after $1 \mathrm{hr}$ at $725 \mathrm{~nm}$ against the blank which contained $40 \mu \mathrm{H}_{2} \mathrm{O}$. Caffeic acid, $10-1000$ ppm, was used as standard for calibration curve. The results were expressed in $\mu \mathrm{g} \mathrm{CAE} \mathrm{g-1}$ of sample.

\section{Analysis of Phenolics Acids}

The phenolics acids were measured on Acquity column UPLC BEH C18 $1.7 \mu \mathrm{m}(2.1 \times 50 \mathrm{~mm})$ (Waters) using PDA detector. Samples were filtered with Millipore. As mobile phase $2 \%$ of acetic acid: methanol $(90: 10 \mathrm{v} / \mathrm{v})$ with $1 \mathrm{ml}$ litre $^{-1}$ eluent was used. The column was maintained at ambient laboratory temperature and wavelength of $280 \mathrm{~nm}$ (Neo et al., 2008). To justify the reliability of this method, we used $2 \mathrm{mg}$ of gallic acid, syringic acid, caffeic acid, chlorogenic acid, p-coumaric acid, 4-hydroxybenzoic acid, ferulic acid dissolved in $2 \mathrm{ml}$ aquades as a standard. One mililitre of the standard (standard:water 1:9 v/v) was injected to the UPLC.

\section{Extraction and Determination of Lignin}

Three zones of oil palm fruit [abscission zone (AZ), mesocarp below the AZ and the pedicle above the AZ] were used for determination of lignin content. The samples were treated with ethanolbenzene to eliminate the extractive compounds. Hexane:ethanol $(1: 1 \mathrm{v} / \mathrm{v})$ was added to $5 \mathrm{~g}$ of samples and agitated for $24 \mathrm{hr}$ at room temperature. The extract was filtered and washed with $96 \%$ ethanol to remove excess hexane. The samples were extracted using 95\% ethanol for $4 \mathrm{hr}$. The samples were then filtered and washed with water. The washed samples were placed in Erlenmeyer flask containing $50 \mathrm{ml}$ boiled water and subjected to heat treatment at $100^{\circ} \mathrm{C}$ for $1 \mathrm{hr}$ in boiling water bath. After boiling, the samples were filtered and thoroughly washed with boiled water. The collected samples were dried at room conditions.

The method of Dence and Lin (1992) was used with some modifications for lignin determinations. Approximately $5 \mathrm{ml}$ of $72 \%$ sulphuric acid $\left(\mathrm{H}_{2} \mathrm{SO}_{4}\right)$ was carefully added into $500 \mathrm{mg}$ (A) of free extractive samples, followed by incubation for 3 $\mathrm{hr}$ at room temperature with gentle shaking to mix the reaction solution every $30 \mathrm{~min}$. The samples were diluted with water until the concentration of sulphuric acid reached $3 \%$. The samples were heated in an autoclave for $30 \mathrm{~min}$ at $121^{\circ} \mathrm{C}$, filtered, dried in an oven and weighed (B). The lignin content was determined by the ratio of final dry weight and initial weight of sample (B/A).

\section{Statistical Analysis}

All the data were analysed with paired t-test statistical analysis using Microsoft Excel 2007.

\section{RESULTS AND DISCUSSION}

\section{Bunch Growth and Development}

The weight of harvested bunches during observations ranged from 15 to $55 \mathrm{~kg}$, and the number of spikelets were around 100 - 300 spikelets per bunch. The FFB and spikelet weight between the normal and hard bunch were significantly different, while other parameters were not significant (Table 1). This data indicated that there were no metabolic disturbances occurring during the bunch growth and development suggesting that the fruits developed normally. This result is supported by the high fruit set $(85.77 \%)$ and oil extraction ratio (OER) $(21.08 \%)$ observed in hard bunches, which are not significantly different from those in normal bunches.

FFB production is one of the most important aspects in oil palm plantation. Although hard 
TABLE 1. CHARACTERISTIC OF NORMAL AND HARD BUNCHES

\begin{tabular}{llll}
\hline \multicolumn{1}{c}{ Characters } & Normal bunches & Hard bunches & T-test \\
\hline Fresh fruit bunch $(\mathrm{kg})$ & $18.46 \pm 1.83$ & $24.32 \pm 1.45$ & $*$ \\
Number of spikelet & $164.00 \pm 21.04$ & $176.61 \pm 10.47$ & $\mathrm{~ns}$ \\
Number of normal fruits & $379.71 \pm 50.10$ & $378.07 \pm 44.33$ & $\mathrm{~ns}$ \\
Spikelet weight $(\mathrm{kg})$ & $3.72 \pm 0.07$ & $4.01 \pm 0.10$ & $*$ \\
Fruit weight $(\%)$ & $7.27 \pm 0.62$ & $7.72 \pm 0.60$ & $\mathrm{~ns}$ \\
Fruit set $(\%)$ & $87.35 \pm 2.26$ & $85.77 \pm 3.39$ & $\mathrm{~ns}$ \\
Oil/ bunch $(\%)$ & $22.73 \pm 1.55$ & $21.08 \pm 1.87$ & $\mathrm{~ns}$ \\
\hline
\end{tabular}

Note: $\mathrm{ns}=$ not significant. *Significant with $\alpha 0.05$.

bunches have high FFB, this can be meaningless if high number of the hard bunches are not detected by the harvesters. If the ripe bunches are not harvested in the correct rotation time (7 - 10 day rotation), the bunch would be over-riped by the next rotation. Based on field observation, some of the hard bunches were not harvested. This can decrease the oil yield, reduce the crude palm oil (CPO) quality [with high free fatty acid (FFA)] and eventually affect the CPO price (Tan et al., 2009).

The oil palm mesocarp contains a high lipase activity. The lipase activity leads to the acidification of mesocarp which releases FFA (Ebongue et al., 2006). The lipase activity can be inactivated by heat treatment. The acidity can be reduced by harvesting the fruits before they become over-ripe. The high FFA content is known to be unhealthy for human consumption (Ebongue et al., 2008) and should be removed.

Oil extraction obtained from normal bunches $(22.73 \%)$ and hard bunches $(21.08 \%)$ was not significantly different. These results were also not much different from the OER average produced in Lampung which ranged from $22 \%-24 \%$. Oil biosynthesis starts at 12 to 13 weeks after pollination. In this stage, lipid starts to accumulate in endosperm and little oil accumulates in mesocarp (Oo et al., 1985). On the other hand, lipid accumulation in mesocarp starts in 16 to 17 weeks after pollination and this is indicated by the increase in fruit size and mesocarp fresh weight (Oo et al., 1985; Tranbarger et al., 2011).

\section{Biochemical Component}

Total carotene, chlorogenic acids, ferrulic acids, and lignin of fruit abscission zone of hard bunch fruits were significantly different from the fruits of normal bunches (Table 2). In plants, carotenoids are essential components for the production of carotenoid-derived phytohormones ABA and strigolactone (Cazzonelli, 2011).

Ramakhrisna and Ravishankar (2011) reported that accumulation of these compound often occurs when the plant experiences stress as a function of the plant adaptation to the environment. Neo et al. (2008) reported that palm oil contains many antioxidants that work well for human health such as carotenoid, tocopherol, and phenolic compound. These compounds are involved in plant defense mechanisms against drought stress.

Phenolic compounds, phenolic acids and their derivatives and polyphenols have important role in detoxification of free radicals (Ksouri et al., 2007). This compounds also play an important role in the life cycle of plant including growth, reproduction and defence to abiotic and biotic stresses. Polyphenolic compounds are also used as substrates by the enzyme peroxidase against $\mathrm{H}_{2} \mathrm{O}_{2}$ (Yildiz-Aktas et al., 2009).

Furthermore, one of transcripts which was differentially expressed in hard bunches analysis was peroxidase (Roberdi et al., 2015). One of the peroxidase functions in plant is known to beinvolved in lignifications process in tobacco (Marjamaa et al., 2008). Detoxification in plants occurs via two ways, namely enzymatic and non-enzymatic. A common response is by increasing the synthesis of phenolic compounds (Parida et al., 2004).

One of the phenolics accumulated during drought is lignin. Lignin serves as a plant defense system against stress. Lignin allows the cell wall to be impermeable to water, allowing the transport of organic material in xylem tissue. However, although lignin has a good function for plants, but a high lignin content can cause problems in industrial use.

The high lignin content in abscission zone of the fruits in hard bunches was thought to cause the hard bunch phenomena. Abscission is the process of cell division so that the plant can form some organs, such as leaves, flowers and fruits. Abscission occurs at a location called abscission zone. The occurrence of abscission process involves the coordination of many biochemical processes.

Henderson and Osborne (1994) stated that oil palm fruit abscission occurs in two stages, the first stage is the separation of cells from fruit pedicle 
TABLE 2. BIOCHEMICAL CHARACTERS IN NORMAL AND HARD BUNCHES

\begin{tabular}{|c|c|c|c|c|}
\hline Biochemical characters & Units & Normal bunches & Hard bunches & T-test \\
\hline$\beta$-carotene & $\mathrm{mg} \mathrm{g}^{-1}$ & $11.99 \pm 2.80$ & $13.14 \pm 1.60$ & ns \\
\hline Tocopherol & $\mu \mathrm{g} \mathrm{g}^{-1}$ & $118.57 \pm 26.13$ & $111.20 \pm 13.13$ & ns \\
\hline Total carotene & $\mu \mathrm{g} \mathrm{g}^{-1}$ & $111.50 \pm 17.90$ & $206.90 \pm 33.80$ & * \\
\hline Total phenolic & $\mu \mathrm{g} \mathrm{g}^{-1}$ & $525.40 \pm 57.00$ & $503.10 \pm 37.00$ & ns \\
\hline Phenolic acid profiles 4-hydroxybenzoic acid & $\mu \mathrm{g} \mathrm{g}^{-1}$ & $120.00 \pm 9.00$ & $95.90 \pm 6.00$ & * \\
\hline Caffeic acid & $\mu \mathrm{g} \mathrm{g}^{-1}$ & $25.00 \pm 0.42$ & $20.00 \pm 0.09$ & ns \\
\hline Chlorogenic acid & $\mu \mathrm{g} \mathrm{g}^{-1}$ & $55.70 \pm 0.57$ & $34.40 \pm 0.45$ & * \\
\hline Ferrulic acid & $\mu \mathrm{g} \mathrm{g}^{-1}$ & $35.00 \pm 0.27$ & $42.90 \pm 0.24$ & * \\
\hline Gallic acid & $\mu \mathrm{g} \mathrm{g}^{-1}$ & $331.30 \pm 42.00$ & $301.20 \pm 24.00$ & ns \\
\hline p-coumaric acid & $\mu \mathrm{g} \mathrm{g}^{-1}$ & $10.00 \pm 0.01$ & $8.20 \pm 0.01$ & ns \\
\hline Syringic acid & $\mu \mathrm{g} \mathrm{g}^{-1}$ & $5.00 \pm 0.02$ & $4.10 \pm 0.01$ & ns \\
\hline \multicolumn{5}{|l|}{ Lignin } \\
\hline Lignin of fruit AZ & $\%$ & $70.61 \pm 0.97$ & $76.41 \pm 1.65$ & * \\
\hline Lignin of mesocarp & $\%$ & $72.29 \pm 0.98$ & $73.89 \pm 0.51$ & ns \\
\hline Lignin of pedicle & $\%$ & $59.42 \pm 3.70$ & $66.86 \pm 2.53$ & ns \\
\hline
\end{tabular}

Note: ns - not significant at $\alpha 0.05$. *Significant at $\alpha 0.05$.

and it is initiated by ethylene or a precursor, and the second stage is the separation of cells in the area tepals which depends on the release of the first phase. The release process at the second stage is determined by the age and maturity of the fruit. Tranbarger et al. (2011) reported that cell separation occurs at two successive zones, namely, primary abscission zone then abscission zone boundaries. There is a report claiming that ethylene only induces separation on the main abscission zone, meanwhile the detailed mechanisms on how signaling induces separation in the abscission zone boundaries are still unknown. The existence of high lignin in the abscission zone allegedly prevent fruits separation in hard bunches and therefore, the fruits remains attached in bunches after fruit separating process in the oil palm mill.

Abscission zone has several layers of cells. During abscission, degradation of cell wall is confined to the layer of cells which are not lignified. The ripe oil palm fruit was found to have a lower lignin content in the abscission zone (Henderson et al., 2001). These results are in agreement with the findings of Teh et al. (2014) which found that the activity of enzymes Caffeic acid 3-O-methyltransferase (COMT) and Caffeoyl CoA 3-O-methyltransferase
(CCOMT) played a role in the biosynthesis of lignin, and the activity of these enzymes gradually decreased in oil palm fruits 12 to 22 weeks after anthesis.

Radial and longitudinal cross-section of fruits from normal and hard bunches seem to be different (Figures $1 a, 1 b$ and 1c). In normal fruit, abscission zone was clearly visible at the base of the fruit. Whereas in hard bunch fruit, abscission zone was unclear and with many fibres extending from the mesocarp to the fruit stalk. Visually, fibre thickness in normal fruits was thinner or finer than the fibres in hard bunch fruits (Figures $1 d$ and 1e).

The presence of fibres and high lignin content in the abscission zone of fruits in the hard bunches is the main cause that hinders detachment of this fruit from their fruit bunches. Low lignin content will facilitate shedding of ripe fruits after parenchyma cells separate from each other. Lignifications cause cell to resist enzymatic degradation which causes the organs to remain attached to the plant (Rajani and Sundaresan, 2001). Deposition of lignin acts as a physical barrier for the protective layer of the organ which is still attached to the fruit stalk (Agusti et al., 2008). Lignin serves not only as a reinforcement of the plant but also as a mechanical means against

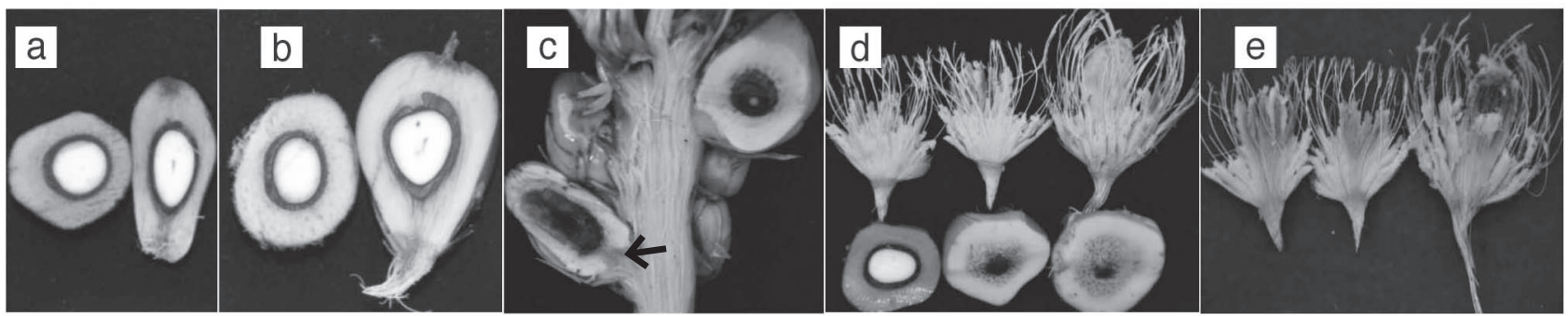

Figure 1. Radial and longitudinal cross-section: (a) normal fruit, with clear abscission zone $(\rightarrow)$, (b) hard bunch fruit with unclear abscision zone, (c) hard bunch fruits which remain attached to pedicle, (d) fibre of normal fruit, (e) fibre of hard bunch fruit. 
pathogen attack and environmental stress (Moura et al., 2010).

Lignin can be formed due to drought stress in plants. It has been reported that the stress from drought can increase the expression of genes which are involved in the lignin biosynthesis such as cinnamoyl-CoA reductase 1 and cinnamoyl-CoA reductase 2 (Yoshimura et al., 2008). Drought stress can also increase the activity of enzymes guaiacol peroxidase, coniferyl alcohol peroxidase and peroxidase syringaldazine (Bok-Rye et al., 2007). We found transcript of peroxidase by using differential analysis (Roberdi, 2014).

\section{CONCLUSION}

The physical and biochemical characters showed that the significant difference between hard bunches and normal bunches were at the FFB, spikelet weight, total carotene, 4-hydroxybenzoic acid, chlorogenic acid, ferulic acid and abscission zone of lignin. Carotenois and phenolic acids are essential compound for plants to adapt with the environmental stresses.

On the other hand, spikelet number, number of normal fruits, fruit weight, fruit set, OER, $\beta$-carotene, tocopherol, total phenolic, caffeic acid, gallic acid, p-coumaric acid, syringic acid, mesocarp lignin, pedicle lignin, were not significantly different between the two types of bunches.

\section{ACKNOWLEDGEMENT}

This research was fully funded by PT Smart Tbk. The authors would like to express their great appreciation to the management for permission to publish this article. Author are also grateful to Randi Abdur Rohman for biochemical analysis, Hadi Septian Guna Putra for statistical analysis and Reflinur for reviewing the manuscript and valuable suggestion.

\section{REFERENCES}

AGUSTI, J; MERELO, P; CERCOS, M; TADEO, F R; and TALON, M (2008). Ethylene-induced differential gene expression during abscission of citrus leaves. $J$. Exp. Bot., 59(10): 2717 - 2733.

BERCHMANS, H J and HIRATA, S (2008). Biodiesel production from crude Jatropha curcas L. seed oil with a high content of free fatty acids. Biores. Technol., 99(6): 1716 - 1721.

BOK-RYE, L; KIL-YONG, K; WOO-JIN, J; AVICHE, J, C; ALAIN, O and TAE-HWAN, K (2007). Peroxidases and lignification in relation to the intensity water deficit stress in white clover (Trifolium repens L.). J. Exp. Bot., 58(6): 1271-1279.

CANO-DELGADO, A; PENFIELD, S; SMITH, C; CATLEY, M and BEVAN, M (2003). Reduced cellulose synthesis invokes lignification and defense responses in Arabidopsis thaliana. Plant J., 34(3): 351362.

CAZZONELLI, C I (2011). Carotenoids in nature:insights from plants and beyond. Functional Plant Biology, 38: 833-847.

CORLEY, R H V and TINKER, P B (2003). The Oil Palm. $4^{\text {th }}$ Edition. Blackwell Science, Oxford.

DENCE, C W and LIN, S Y (1992). Methods in Lignin Chemistry. Berlin: Springer Verlag.

EBONGUE, G F N; KOONA,P; NOUY, B; ZOK, S; CARRIERE, F; ZOLLO, P H A and ARONDEL, $\mathrm{V}$ (2008). Identification of oil palm breeding lines producing oils with low acid values. Eur. J. Lipid. Sci. Tech., 110(6): 505-509.

EBONGUE, G F N; DHOUIB, R; CARRIERE, F; AMVAM, Z P H; and ARONDEL, V (2006). Assaying lipase activity from oil palm fruit (Elaeis guineensis Jacq.) mesocarp. Plant. Physiol. Biochem., 44: 611-617.

FUCHS, H; HAGER, C; FIRGO, H; LAMIENMEDA, A; ZITTERL, K and FRANZ, C (2010). Identifications of plant compounds in lenzing fibers. Lenzinger. Berichte., 87: 117-123.

GIBON, V; DE-GREYT, W and KELLENS, M (2007). Palm oil refining. Eur. J. Lipid. Sci. Tech., 109: 315- 335.

HENDERSON, J and OSBORNE, D J (1994). Intertissue signalling during the two-phase abscission in oil palm fruit. J. Exp. Bot., 45(276): 943-951.

HENDERSON, J; DAVIES, H A; HEYES, S J and OSBORNE, D J (2001). The study of a monocotyledon abscission zone using microscopic, chemical, enzymatic and solid state 13C CP/MAS NMR analyses. Phytochemistry, 56: 131-139.

KSOURI, R; MEDDICHE, W; DEBEZ, A; FALLEH, H; GRIGNON, C and ABDELLY, C (2007). Salinity effects on polyphenol content and antioxidant activities in leaves of the halophyte Cakile maritima. Plant Physiol. Biochem., 45: 244 - 249.

MARJAMAA, K; KUKKOLA, E $M$ and FAGERSTEDT, K V (2008). The role of xylem class III peroxidases in lignification. J. Exp. Bot., 60: 367-376. 
MOURA, J C M S; BONINE, C A V; VIANA, J O F; DORNELAS, M C and MAZZAFERA, P (2010). Abiotic and biotic stresses and changes in the lignin content and composition in plants. J. Integr. Plant. Biol., 52(4):360-376.

MPOB (2005). P2.6: Determination of carotene content. MPOB Test Methods. MPOB, Bangi. p. 194 - 197.

NEO, Y P; ARIFIN, A; TAN, C P and TAN, Y A (2008). Determination of oil palm fruit phenolic compounds and their antioxidant activities using spectrophotometric methods. Int. J. Food. Scie.Techn., 43(10): 1832-1837.

NG, M H; CHOO, Y M; MA, A N; CHUAH, C H and HASHIM, M A (2004). Separation of vitamin E (tocopherol, tocotrienol, and tocomonoenol) in palm oil. Lipid., 39: 1031-1035.

OO, K C; TEH, S K; KHOR, H T and ONG, A S H (1985). Fatty acid synthesis in the oil palm (Elaeis guineensis): incorporation of acetate by tissue slices of the developing fruit. Lipid., 20(4): 205-210.

PARIDA, A K; DAS, A B and MOHANTY, P (2004). Investigations on the anti-oxidative defense responses to $\mathrm{NaCl}$ stress in a mangrove, Bruguiera parviflora: differential regulations of isoforms of some anti-oxidative enzymes. Plant. Growth. Regul., 42: 213-226.

PING, B T Y and GWENDOLINE, E C L (2006). Identification of lutein in crude palm oil and evaluation of carotenoids at various ripening stages of the oil palm fruit. J. Oil. Palm. Res. Vol. 18: 189-197.

RAJANI, S and SUNDASRESAN, V (2001). The Arabidopsis myc/bHLH gene ALCATRAZ enables cell separation in fruit dehiscence. Curr. Biol., 11: 1914 - 1922.

RAMAKRISHNA, A and RAVISHANKAR, G A (2011). Influence of abiotic stress signals on secondary metabolites in plants. Plant. Signal. Behav., 6(11): 1720-1731.
ROBERDI (2014). Physiological and Moleculer Analysis of Hard Bunch Phenomenon in Oil Palm Fruits. Ph.D Dissertation. Bogor Agricultural University.

ROBERDI; SOBIR; YAHYA, $\mathrm{S}$ and TORUANMATHIUS, N (2015). Differential analysis of gene related to hard bunch phenomena in oil palm (Elaeis guineensis Jacq.) fruits. Emir. J. Food and Agriculture, 27(8): 596-601.

TAN, C H; GHAZALI, H M; KUNTOM, A; TAN, C P and ARIFFIN, A A (2009). Extraction and physicochemical properties of low free fatty acid crude palm oil. J. Food. Eng., 113(1): 645-650.

TEH, H F; NEOH, B K; WONG, Y C; OOI, K Q B; KEONG, T E; NG, T L M; TIONG, S $\mathrm{H}$; LOW, J K S; DANIAL, A D; ERSAD, $M$ A; KULAVEERASINGAM, $\mathrm{H}$ and APPLETON, D R (2014). Hormones, polyamines and cell wall metabolism during oil palm fruit mesocarp development and ripening. J. Agric. Food Chem. DOI: $10.1021 /$ jf500975h.

TRANBARGER, T J; DUSSERT, S; JOET, T; ARGOUT, X; SUMMO, M; CHAMPION, A; CROS, D; OMORE, A; NOUY, B and MORCILLO, F (2011). Regulatory mechanism underlying oil palm fruit mesocarp maturation, ripening, and functional specialization in lipid and carotenoid metabolism. Plant. Physiol., 156: 564-584.

YILDIZ-AKTAS, L; DAGNON, S; GUREL, A; GESHEVA, E and EDREVA, A (2009). Drought tolerance in cotton: involvement of non-enzymatic ROS scavenging compounds. J. Agron. Crop. Scie., 195(4): 247-253.

YOSHIMURA, K; MASUDA, A; KUWANO, M; YOKOTA, A and AKASHI, K (2008). Programmed proteome response for drought avoidance/tolerance in the root of a C-3 Xerophyte (wild watermelon) under water deficits. Plant. Cell Physiol., 49(2): 226241. 